\title{
食料供給システムの物質・エネルギー解析と 低炭素型の食生活に関する研究
}

\author{
長沼 悠介 1 - 立花 潤三 2 ・後藤 尚弘 3 \\ 1非会員 元豊橋技術科学大学 環境・生命工学系（干441-8580 愛知県豊橋市天伯町雲雀ヶ丘1-1） \\ 2正会員 富山県立大学 環境工学科（干939-0398 富山県射水市黒河5180） \\ E-mail: tatibana@pu-toyama.ac.jp \\ 3 正会員 豊橋技術科学大学 環境・生命工学系（干441-8580 愛知県豊橋市天伯町雲雀ヶ丘1-1） \\ E-mail:goto@ens.tut.ac.jp
}

\begin{abstract}
本研究では, 代表的な食料 8 種類について, 食料供給システム（食料生産・流通・消費）における食料 フローを解析し，1965年から2005年までの各消費量，食品ロス量，食料供給に係る投入エネルギー及び二 酸化炭素排出量を明らかにした。二酸化炭素排出量は 2005 年において約 5,400 万t $-\mathrm{CO}_{2}$ (日本の二酸化炭素 総排出量の約 $4.5 \%$ ）であることが明らかになった。また，国民が摂取した熱量（摂取熱量）と食料供給 に要した熱量（投入エネルギー）の乘離幅と食品廃棄物量に関係があることが明らかになった，そして， 必要とする栄養素量を満たしながら，投入エネルギーが最も少ない低炭素型の食生活を線形計画法によっ て明らかにした。その結果，穀類・豆類・肉類等の攝取を増加し，野菜類・魚介類等の捸取を減少させる 解が得られた。この食生活を日本人全員が行うと，年間で約 500 万t $-\mathrm{CO}_{2}$ の削減が可能である.
\end{abstract}

Key Words : food system,sutainability,food waste, $\mathrm{CO}_{2}$,eating habits

\section{1. 序論}

(1) はじめに

\section{a）食品廃棄物}

平成 20 年の食品廃棄物排出量が約 1800 万 $\mathrm{t}$ であり, その内訳は一般廃棄物が約 1500 万t，産業廃棄物が約 300 万 t である ${ }^{1)}$. 食品廃棄物注(1) は一般廃棄物では約 $30 \%$, 産業廃棄物では約 $1 \%$ を占めている. 日本は食料の半分 以上を輸入しているのにも関わらず，食品資源の約 2 割 を廃棄しているといら報告もある ${ }^{2)}$.

食品リサイクル法の改正により，食品資源の再生利用 率は年々上昇しており，平成 19 年度では，食品製造業 が $81 \%$, 食品卸売業が $62 \%$, 食品小売業が $35 \%$, 外食 産業が $22 \%$ となっているが，近年では，再生利用率の 増加率は頭打ちの傾向が見られる ${ }^{3)}$. また，同法は食品 関連業者にの夕発生抑制を義務付けているため, 家庭か らの食品廃棄物の再生利用率は $10 \%$ にも至っていない.

\section{b) 供給熱量と摂取熱量}

わが国では，農林水産省は 1960 年から，食料需給の 全般的動向を把握するため，「食料需給表」1)を作成し ている。また，厚生労働省が 1947 年から，国民の栄養
摂取及び生活習慣を明らかにするために，「国民栄養・ 健康調査」4)を実施している，各資料には，国民 1 人 1 日 当たりの「供給熱量」と国民 1 人 1 日当たりの「摂取熱 量」が記載されている. 供給熱量は国内消費仕向量から 可食分の純食料を算出し熱量換算したもので，摂取熱量 は国民が摂取した食料を熱量換算したものである。供給 熱量と摂取熱量の変遷を図-1 に示す。供給熱量が全て 摂取されていると仮定すれば，供給熱量と摂取熱量の值 は等しくなるが，両者の值は異なっている．2010年の時

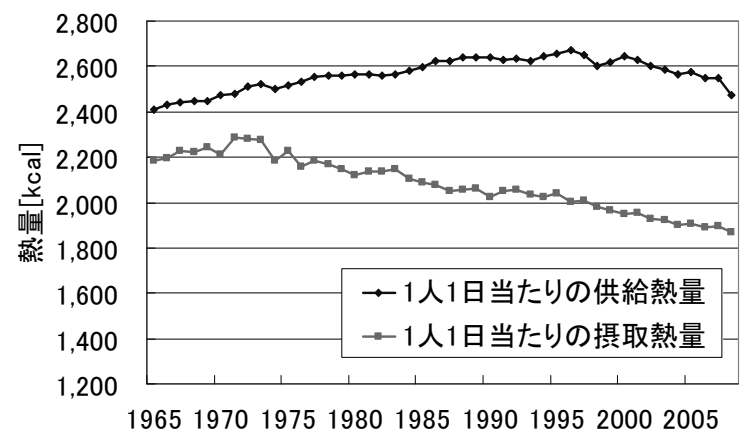

図-1＼cjkstart供給熱量と摂取熱量の変遷 ${ }^{1,5)}(1965-2009)$ 
点で, 両者の乘離幅は約 $610 \mathrm{kcal}$ である．農林水産省は この差は食品の廃棄や食べ残しの目安としているす.

\section{c）食事摄取基準値}

「日本人の食事摂取基準」らは，男女別や年代別の熱 量や各種栄養素の摂取推奨量等の基準值を示している. それによると男女ともに各年代で，摂取基準值よりも実 際の摂取熱量が低いことがわかる。これより, 食品廃棄 の原因は, 食品を過剰に摂取しているためではないこと がわかる．むしろ，日本人はより多くの食料を摂取しな ければならないのに，供給されている食料を摂取せず廃 棄していることがわかる.

\section{d) 食品由来の二酸化炭素排出量の変遷}

農林業・水産業・食料品業の, 1990 年から 2010 年ま での二酸化炭素排出量の変遷を図-2 に示すの. 水産業と 食料品業は 1990 年代前半以降, 農林業は 2000 年代前半 以降から減少傾向になっている.この原因の一つとして, 図-2 が国内分を算出しているため, 食料自給率の低下 がこのような結果になったと思われる. 1990年に48\%で あった自給率は，2010 年で 39\%と，9\%減少している. 特に水産業では，1990年の79\%に対して，2010年は54\% と，25\%減少している．また，水産業では単位生産額当 たりのエネルギー消費量（金額熱量原単位）が大きい漁 業の割合が減少し，金額熱量原単位が小さい養殖業の割 合が増加していることも，原因の一つとして考えられる。

以上より, 我が国の食料需給システムにおいて, 食料 生産のための熱量や食品廃棄物増加などの環境問題と, 栄養摂取が基淮值よりも低いライフスタイルの問題が混 在している.

\section{(2) 既往研究}

\section{a) 食料需給システムに関する研究}

小幡（2012）81は，食料自給率の低下と食料の供給熱 量と摂取熱量の乘離幅の増加や環境負荷の増加との関連 性を指摘している．佐藤（2007）9は，産業連関表とエ ネルギーバランス表を用いて食料部門のエネルギー・環 境負荷の解析や経済への影響分析を行った. 食料品に対 する年間の直接・間接エネルギー消費量は, 総消費量の

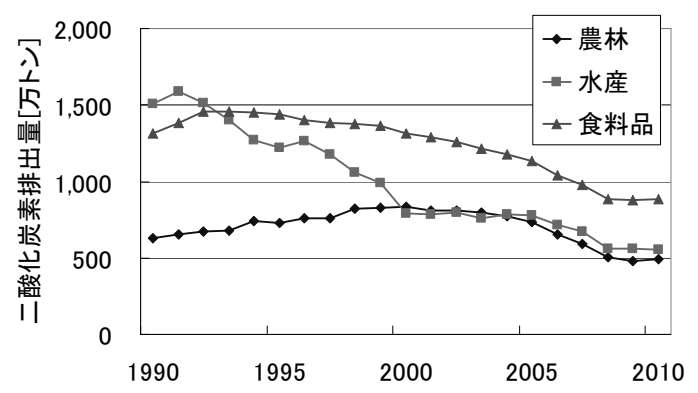

図-2 食料関係の二酸化炭素排出量の変遷6)（1990-2010）
$12.2 \%$ を占め, 食料自給率を平成 27 年度目標值まで高め た場合, エネルギー消費量と二酸化炭素排出量はいずれ も $0.65 \%$ 増と微増であると考察した.

Apaiahetal. (2006） ${ }^{10} /$ は，オランダ国内の豚挽き肉，乾 燥豆から作られたたんぱく質食品等のサプライチェーン の環境負荷を，エクセルギー解析を用いて分析した。乾 燥豆から作られたたんぱく質食品のサプライチェーンは, 豚婏き肉のそれよりも約 1.2 倍効率的であることを明ら かにしている.

\section{b) 食品廃棄物・食品ロスに関する研究}

世界の食品廃棄物と食品ロスに関しては FAO の報告 書 ${ }^{11}$ が世界各地域のデータを示している. 日本はアジア 先進工業地带として中国や韓国とともに分類されている。

須藤・菱田（2010） ${ }^{11}$ は，我が国の食品ロス発生の要 因として, 食品リサイクル法に拡大生産者責任が定めら れていないことを指摘している.

Kantor et al.（1997）12)はアメリカにおける食料サプライ チェーン中に発生する食品ロスの種類と要因を調査した. そして, 10 種類の食料に対して, 小売り, 外食, 消費 者のそれぞれの食品ロス率を算出し，全体で $27 \%$ の食 品ロスが生じていると推定した.

Parfitt et al.（2010）13)は先進国及び発展途上国等におけ る食品廃棄物の定量化と将来予測を行った。 発展途上国 や移行国では, 食料サプライチェーンのインフラ (冷蔵 貯蔵など）が整っていないため, 食料が腐敗しやすくサ プライチェーンの上流で廃棄物発生量が多いが, 先進国 では消費段階での廃棄物が多いことを指摘した.

\section{c) 食料生産の投入されるエネルギーに関する研究}

野口・齋藤（2008） ${ }^{14}$ は，機械化された水稲生産の直 接・間接エネルギーを求める手法を提案した. そして, 過去の機械化水稲生産との比較から，機械や資材の製造 エネルギーの減少や農薬・化学肥料の少量散布による低 熱量消費型水稲生産の可能性を示した. 仁平 (2003) $\left.{ }^{15}\right)$ は, 日本における 32 の作物生産の投入・産出熱量につ いて, 1970 年から 1990 年までを算出し，いも類を高位 効率作物（投入産出熱量比：6.8 9.1）, 穀類と豆類を 中位効率作物（1.7～3.9），果実と露地野菜を低位効率 作物（0.6 1.1），施設作物を極低位効率作物（0.04）と 区分した．吉川ら（2009）1のは，輸入食料・飼料の環境 負荷を考慮した産業連関表による二酸化炭素排出原単位 の作成を目的とし, 小麦と豚肉の輸入と国内生産のライ フサイクルインベントリ分析を行った. その結果輸入製 品の環境負荷の方が低いことが明らかになった.

\section{d）食料摂取の栄養に関する研究}

澤田（1991）17は，所得（特に農業以外）の成長が栄 養の限界価值を低下させる一方, 栄養の相対価格は栄養 の価值に正の有意な効果を与えていることを示唆した.

久保ら（1988）181は，食品を栄養素の含有成分比によ 
り 7つの食品群に分類し, 各種栄養素の摂取量を最適に するための多目的栄養摂取計画モデルを構築した.

\section{(3) 研究目的}

持続可能な社会の形成のためには，生活に欠か寸こと ができない「食」の持続可能性について考慮することが 必要不可欠である.これまで食品リサイクル法などの法 の整備や，地産地消・旬産旬消や CFP(Carbon Footprint of Products)の取り組みを通じて国民意識の向上を図るなど, 様々な対策が施されている．また，「食」の環境負荷に 関する研究も今日まで数多く行われている. しかし, 地 産地消は都市部では限界があり, CFP は対象商品が食料 品以外も含めて現時点で約 630 点であり 7), 普及数が少 ないなどの問題がある. 既往研究では, 食料の流通・消 費段階を含まないものや, 熱量や栄養素の必要摂取量, 食品ロスの熱量を考慮していない場合が多い.

本研究では，「食」の持続可能性を食品ロス量と食品 ロスによる二酸化炭素排出量の観点から提案することと した. つまり，持続社会の一つである低炭素化に焦点を 絞った. 代表的な食料 8 種類について, 食料供給システ 么（食料生産・流通・消費）における食料フローを解析 し, 食品ロス量とそれによる二酸化炭素排出量を計算す る. そして，国民が必要とする栄養素量を満たしながら， 投入エネルギーが最も少ない「低炭素型の食生活」を線 形計画法によって明らかにする.

\section{2. 食料生産に伴う環境負荷評価}

\section{(1) 手法}

\section{a) 対象とする食料需給システム}

本研究での対象食料は, 過去の信頼できるデータが存 在し, かつ, 摂取量の多い代表的な食料として, 穀類 · いも類 - 豆類 - 野菜類 果実類 $\cdot$ 肉類 $\cdot$ 魚介類 $\cdot$ 乳製品 の 8 種類とした. 食料の消費形態は「食品産業（加工 品）」「外食産業」「世帯」の 3 つとし, 流通過程で 「卸売り」や「小売り」がある.これらが絡み合ったの が食品フローである. 各消費形態・流通過程で食品ロス が発生する，ここで，食品ロスとは，本来可食部分であ るが廃葉される廃棄物のことである. 食品廃棄物とは, 食品口スと不可食部分の和であるが，本研究では不可食 部分は考慮しないこととした．また，本研究では食料生 産に要したエネルギ一量を「投入エネルギー」と定義し た. さらに, 本研究では食料生産に伴う投入エネルギー 量を評価することを目的としているので，卸売りや小売 りにおいては, 化石然料の投入エネルギーは考慮せず, 食品廃棄物の発生のみを考慮した。

\section{b) 食料需給システムの食料フローの算出}

国内生産量に輸入量を足して輸出量を引いた值が国内 仕向量であり，不可食部分も含まれている．この不可食 部分を排除したものを純食料とした. データは農林水産 省の食料需給表4)を用いた.

純食料から各消費形態へのフローは式（1）によって 算出した ${ }^{20)}$. 算出は産業連関表がある 1965 年 - 2005 年 まで 5 年ごととし, 産業連関表の産出表の生産者価格を 用いて, 各食料における各消費形態毎の取引金額の比を 算出し，それに産業連関表と同じ年の純食料量を乗じた.

$$
M(i, j)=\frac{O(i, j)}{\sum_{i} O(i, j)} \times F(j)
$$

$M$ : 食料消費量 $(\mathrm{t}) \quad O$ : 産出額 $($ 円) $\quad F$ : 純食料量 $(\mathrm{t})$

$O_{A L L}$ : 食料として使用される産出額合計(円)

$i$ : 食料消費形態 (食品産業, 外食産業, 世帯)

$j$ : 食料の種類（穀類, いも類, 豆類, 野菜類, 果実類, 肉類, 魚介類, 乳製品)

各消費形態の純食料量に食品ロス率を乗ずる(式(2)). 純食料量に，算出した食品ロス量を引いた食料量を，本 研究では「消費量」と定義する.

$$
M_{\text {Loss }}(i, j)=M(i, j) \times R_{\text {LosS }}(i, j)
$$

$M_{L O S S}$ : 食品ロス量 $(\mathrm{t})$

$R_{\text {LOSS }}$ : 重量あたりの食品ロス率(\%)

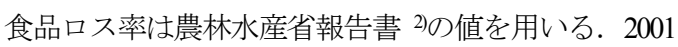
年の報告書以降は, 世帯の食品ロス率データのみの公表 である，そのため, 外食産業, 食品卸売業, 食品小売業 の食品ロス率は，2000年の值を他の年にも適用した．た だし, 食品製造業の食品ロス率は, 「商品の廃棄のみで 原材料の廃棄を考慮していない」21)との指摘もあること から別途算出した. 農林水産省公表の「食品廃棄物等の 年間総発生量及び発生抑制の実施量」22)廃棄としての 処分量が，式(1)で算出した食品産業の消費量（純食料 に相当）に対する割合を求めた。また，食品産業へは食 品卸売業から食料が流通寸るとしたので，この割合に食 品卸売業の食品ロス率を足したものを食品産業の食品口 ス率とし, 食品卸売業の食品ロスを食品産業に含めて算 出した. 同様に, 外食産業の食品ロス率は外食産業と食 品卸売業の食品ロス率の和, 世帯の食品ロス率は世帯と 食品小売業の食品ロス率の和として算出した.

\section{c) 投入エネルギーと摂取熱量}

投入エネルギーは産業連関表産出表の各食料の生産に 伴う生産者価格に, 産業連関表による環境負荷原単位デ ータブック 23)（以下3EID）の金額熱量原単位を乗じて熱 量に換算した. 計算式を式（3）に示す. 


$$
\begin{aligned}
E_{\text {INPUT }} & =\sum_{j=1}^{8}\left\{\sum_{i=1}^{3}\left(O(i, j) \times C_{H}(j)\right)\right. \\
& \left.+\sum_{k}\left(O(k, j) \times C_{H}(k)\right)+\sum_{l}\left(O(l, j) \times C_{H}(l)\right)\right\}
\end{aligned}
$$

$E_{\text {NPUT }}$ : 食料の投入エネルギー( $(\mathrm{kcal}) \quad O$ : 産出額(円) $C_{H}$ : 金額熱量原単位 $(\mathrm{kcal} /$ 円) $k$ : 原料段階の分類 $l$ : 農林水産等で使用される化学肥料等その他の分類

式（3）の右辺第 1 項は消費段階での投入エネルギー を, 第 2 項は各食料の原料段階での投入エネルギーを, 第 3 項は農林水産や畜産で使用される化学肥料や飼料の 投入エネルギーを表している．なお，それぞれの段階に おいて化石然料の投入エネルギーが含まれている， $k, l$ の分類を表- 1 に示寸.

また, 日本は食料の半分以上を輸入に依存しているの で, 本研究では 3EID の「輸入品国内生産仮定型」を適 用した. ただし，大規模農園等の海外の原単位は，日本 の原単位よりも小さい可能性があり ${ }^{10}$, 本研究で求める

表-1 各食料産業連関表における原料段階, その他の分類

\begin{tabular}{|l|c|l|}
\hline & \multicolumn{1}{|c|}{ 原料段階 } & 化学肥料や飼料等その他 \\
\hline 穀類 & - & 化学肥料, 農薬 \\
\hline いも類 & - & 化学肥料, 農薬 \\
\hline 豆類 & - & 化学肥料, 農薬 \\
\hline 野菜類 & - & 化学肥料, 農薬 \\
\hline 果実類 & - & 化学肥料, 農薬 \\
\hline 肉類 & $\begin{array}{l}\text { 肉鶏, 豚, 肉用牛, その他 } \\
\text { の畜産 }\end{array}$ & 飼料 \\
\hline 魚介類 & $\begin{array}{l}\text { 海面漁業, 海面養殖業, 内水 } \\
\text { 面漁業・養殖業 }\end{array}$ & $\begin{array}{l}\text { 海面養殖業, 内水面養 } \\
\text { 殖業 }\end{array}$ \\
\hline 乳製品 & 酪農 & 飼料 \\
\hline
\end{tabular}

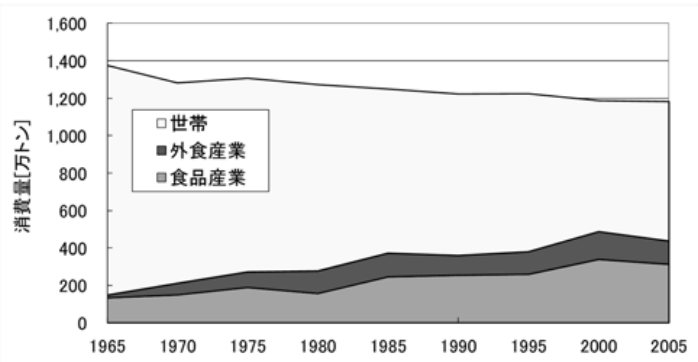

図-3 消費形態別の穀類の消費量の変遷（5年毎)

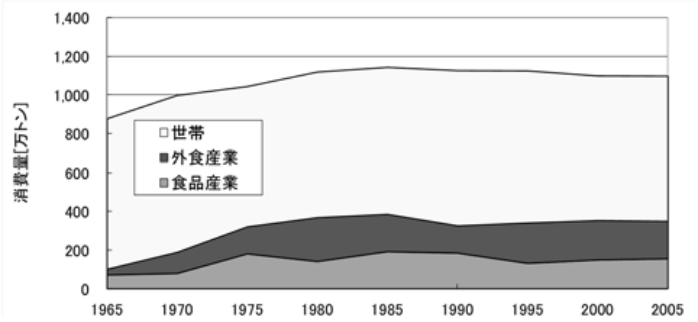

図-4 消費形態別の野菜類の消費量の変遷（5年毎)
值は現実より大きい可能性がある.

㩒取熱量は，厚生労働省の「国民健康・栄養調查」 24) の各食料の 1 人 1 日あたりの摂取熱量より算出した.

\section{d) 食料生産に伴う二酸化炭素排出量の算出}

食料生産に伴う二酸化炭素排出量は式(3)の金額熱量 原単位の換わりに，3EID の金額二酸化炭素排出原単位 を乗ずることで算出した．食品ロスに由来する二酸化炭 素排出量（食料生産に伴う二酸化炭素排出量のうち食品 ロス分）は，各食料の二酸化炭素排出量に食品ロス率を 乗じて算出した．従って，食品ロスの処理，発酵等によ る二酸化炭素，メタン等は考慮していない.

\section{(2)結果}

\section{a) 食料需給システムの形態別食料消費量}

各食料における消費形態別の消費量の変遷を図-3 ら図-5 に示す．穀類は，世帯消費が減少する一方で外 食・食品産業での消費が増加してきたことが分かる．野 菜類は外食・食品産業での消費が一時増加しその後大き な変化がなく推移している，肉類は外食・食品産業での 消費が増加傾向を示した.

\section{b) 食料需給システムの食品ロス量}

各食料の消費形態別の食品ロス量の変遷を図-6 から 図-8 に示寸. 野菜類の食品口ス量が他の食料と比較し て多くなっている．また，その内訳として世帯からの食 品ロスが多いことが分かる．なお食品産業の食品ロス量 は 2(1)b)に示寸ように不可食部分が含まれており世帯, 外食産業のそれよりも多く見積もられている. 全体的に

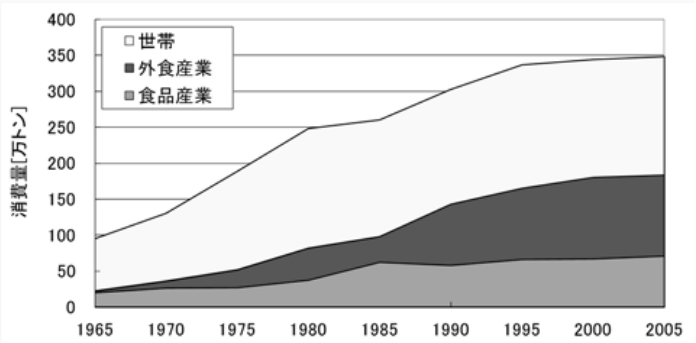

図-5 消費形態別の肉類の消費量の変遷（5年毎）

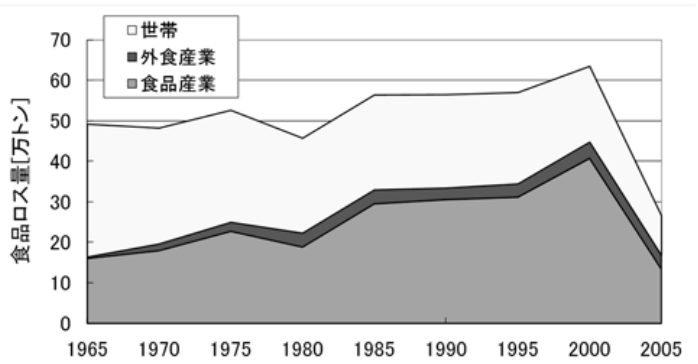

図-6 消費形態別の穀類の食品ロス量の変遷（5年毎） 
2000年を境に各食料の食品ロス量が減少していることが わかる. 外食産業に関しては 2000 年に改正の食品リサ イクル法の影響が，世帯に関しては食品ロス量の算定方

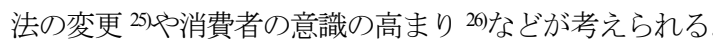
c) 食料生産に伴う投入エネルギ一と食料㩒取による摄取 熱量

各食料の食料生産に伴う投入エネルギーと食料摂取に

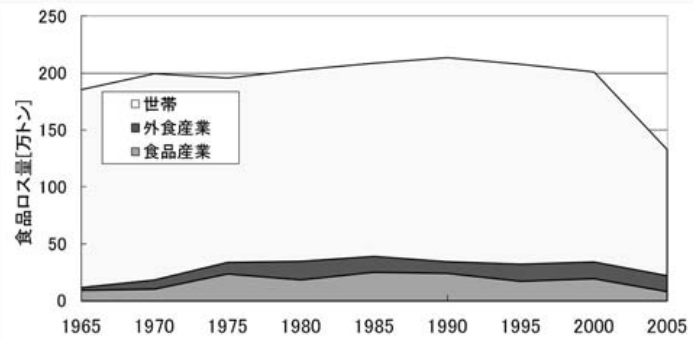

図-7 消費形態別の野菜類の食品ロス量の変遷（5年毎）

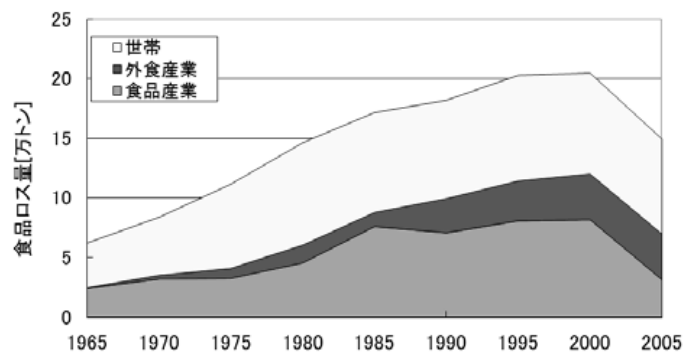

図-8 消費形態別の肉類の食品ロス量の変遷（5年毎）

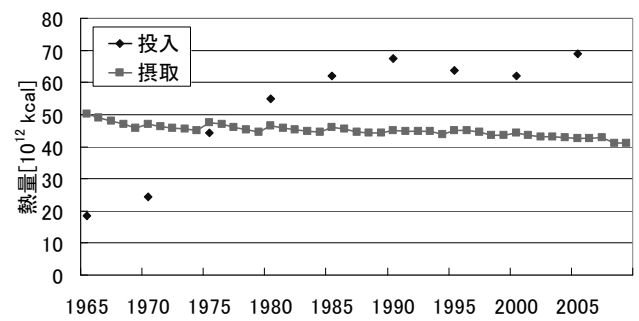

図-9 穀類の投入エネルギーと摂取熱量の変遷(1965-2009)

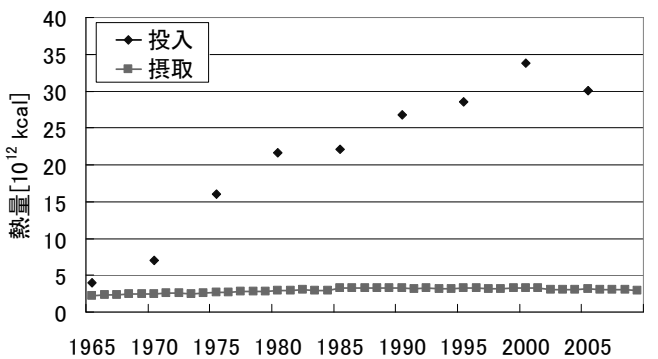

図-10＼cjkstart野菜類の投入エネルギーと摂取熱量の変遷(1965-2009)
よる摂取熱量の変遷を図-9 から図-11 に示寸。各食料の 摂取 $1 \mathrm{kcal}$ あたりの投入エネルギーの変遷を図-12 に示す. 穀類, 野菜類, 肉類ともに，摂取熱量は大きく変わらな いが投入エネルギーが増加しているのが分かる．図-12 をみると, 特に魚介類と野菜類の増加が顕著である.

\section{d) 食料生産に伴う二酸化炭素排出量の結果}

食料生産に伴う二酸化炭素排出量の変遷を図-13 に示 す. 1965 年以降, 食料生産に伴う二酸化炭素排出量は増 加し続け，1985 年のピーク時には約 5 倍まで増加し, 2009 年には約 5000 万 $\mathrm{tCO}_{2}$ となった. 食料生産に伴う二 酸化炭素排出量の割合は，日本の全二酸化炭素排出量 6) の約 4.5\%(2005 年)となった. 食品ロス由来の二酸化炭素 排出量は，食料生産に伴う二酸化炭素排出量の約 $5.3 \%$ である，なお，図-2では二酸化炭素排出量は減少して

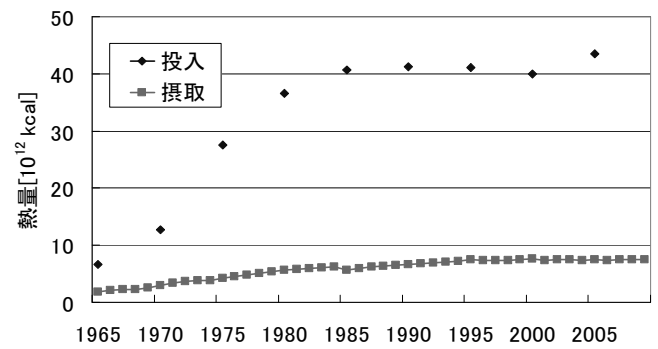

図-11 肉類の投入エネルギーと摂取熱量の変遷(1965-2009)

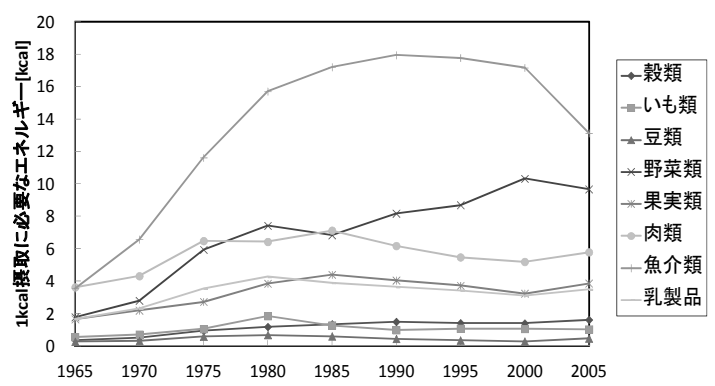

図-12 各食料の摂取 $1 \mathrm{kcal}$ あたりの投入エネルギーの変遷

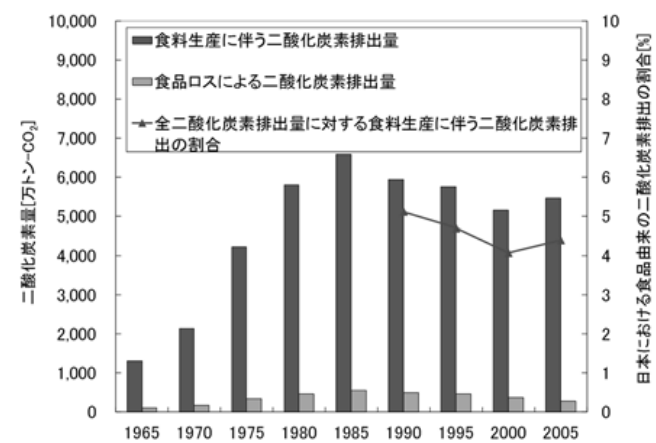

図-13 食料生産に伴う二酸化炭素排出量の変遷 


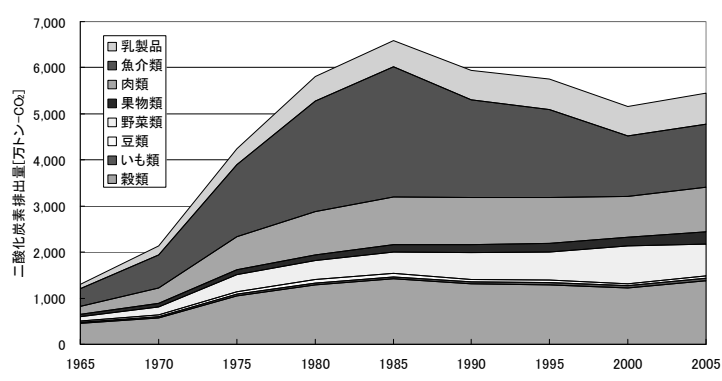

図-14 食料別の生産に伴う二酸化炭素排出量の変遷（5年毎）

表-2 熱量換算係数 $(\mathrm{kcal} / \mathrm{g})$

\begin{tabular}{|c|c|c|c|c|c|c|c|}
\hline 颉類 & いも類 & 豆類 & 野菜類 & 果実類 & 肉類 & 魚介類 & 乳製品 \\
\hline 3.59 & 0.9 & 4.15 & 0.28 & 0.54 & 2.16 & 1.32 & 0.62 \\
\hline
\end{tabular}

表-3 熱量換算係数 $(\mathrm{kcal} / \mathrm{g})$

\begin{tabular}{|l|l|l|}
\hline & 2000 & 2005 \\
\hline 食品廃衰物による熱量ロス量 & 515 & 380 \\
\hline 供給熱量と摂取熱量の乘離幅 & 695 & 669 \\
\hline 供給熱量と摂取熱量の乘離幅 (補正) & 495 & 469 \\
\hline
\end{tabular}

いるが，図-13 では増加を示している。これは，図-2 は 国内生産に関連する排出量のみを対象としていが，図一 13 では輸入分も算入しているためである.

また，図-14に食料別の食料生産に伴う二酸化炭素排 出量を示す．魚介類が最も多く，次いで穀類，肉類が多 い結果となった. 1985年以降，魚介類の自給率の低下や 漁業から養殖業への転換により，魚介類の食料生産に伴 う二酸化炭素排出量は減少したが，2005年の時点でも多 くの割合を占める.

\section{e) 供給熱量と摂取熱量の乘離幅と食品廃棄物による熱量 ロスの関係性}

図-1 で示した供給熱量と摂取熱量の乘離幅と算出し た食品廃棄物による熱量ロスを比較した。なお，図-1 における供給熱量は統計表 ${ }^{4)}$ の粗食料注(2)を元にした数值 である.この粗食料には不可食部分の廃棄物も含まれる と考えられるため, 食品口スではなく, 食品廃棄物によ る熱量ロスを比較対象とした.

まず，重量を熱量に換算する係数 $(\mathrm{kcal} / \mathrm{g})$ を，統計 表4から求めた. 求めた換算係数を表-2 に示寸.

次に, 熱量換算係数 $(\mathrm{kcal} / \mathrm{g})$ と食品ロス量 $(\mathrm{g})$ から 食品ロスによる熱量ロス（kal）を算出した。 また，食 品ロスによる熱量ロスと, 食品ロス量と不可食部分の比 から, 食品廃棄物による熱量ロスを求めた。

乘離幅が増加する以前の 1965 年から 1975 年の乘離幅 は，一定で推移しており，その幅は約 200kcal である 5. 1975年以降はこの乘離幅が増加しているので, この増加 分は高度経済成長後の食生活の変化の影響と考えられる.
このため, 1965 年から 1975 年の乘離幅である 200kcal は 通常の生活で避けられない乘離幅とした. 乘離幅から $200 \mathrm{kcal}$ をいた補正值と, 食品廃棄物による熱量ロスを 比較を表-3 に示寸. なお, 食品廃棄物のデータは環境 省公表のデータ 27を用いたため, 2000 年と 2005 年の推 計とした.

表-3 より, 食品廃棄物による熱量ロスと供給熱量と 摂取熱量の乘離幅の補正值が，2000 年ではほぼ同等, 2005年では約 20\%の差異が生じた。これより，乘離幅の 原因及びその熱量の行方が食品廃棄物である可能性が示 唆された.より詳細な検証には, 各部門の食品廃较物の 積み上げデータなどを用いた評価が必要となる.

\section{3.「低炭素型の食生活」の検討}

本章では，前章までに行った食料需給システムにおけ るエネルギー消費量, 二酸化炭素排出量の算定手法を用 いて, 低炭素型の食生活の可能性を検討寸る. 本研究で は「低炭素型の食生活」を, 摂取基準值の熱量及び栄養 素量の摂取を満たしながら，より投入エネルギーが低い 食生活と定義する.

なお, 前章の結果では食品ロスによる二酸化炭素排出 量を推計する一方で, 本章の計算では食品ロス量を変数 とせずに，食品摂取のパターンを変数としている．これ は, 食生活の変化が間接的に二酸化炭素排出量の多い食 品を減らすと考えたからである. 食品ロスを直接へらす 加工技術, 流通形態, 料理方法の変化は重要な変数では あるが，本研究では含まないとした。

\section{(1) 手法}

\section{a)栄養素の摂取基準値について}

本研究で用いる食料 8 種類の摂取熱量は, 全体の熱量 摂取量の約 8 割にあたるため, 国が定める摂取基準值の 8 割の值を本研究の摂取基準值と設定した. また, 年 代 - 男女別人口の加重平均を求め摂取基隻值とした.

\section{b) 定式化}

目的関数: $E_{\text {input }} \rightarrow \mathrm{min}$

制約条件: $\sum_{j=1}^{8} p_{j} \cdot n_{j}^{r} \geq N_{r}$

$$
p_{j} \leq P_{j} \quad(j=1,2, \cdots 8)
$$

$j$ : 食料品種, $P_{j}$ : 食料品種 $j$ の生産量 $(\mathrm{t}), \quad n_{j}^{r}$ : 食料品 種 $j$ に含まれる栄養素 $r$ の量 $(\mathrm{g} / \mathrm{t}), N_{r}$ : 栄養素 $r$ の攝取 基準量 $(\mathrm{t} / \mathrm{year}), P_{j}$ : 食料品種 $j$ の過去最大摂取量 $(\mathrm{t} / \mathrm{year})$ 本問題は, 各種栄養素量と熱量の摂取基淮值を満たす 
ことを制約条件として，投入エネルギーの最小化を目的 関数とする線形計画問題となる. 最大摂取量と最小摂取 量は1953〜2009年の各食料摂取量の最大・最小を用いた。

\section{c) 低炭素型の食生活のシナリオ}

シナリオ設定においては，「熱量の摂取のみを考慮す る場合」「熱量の摂取と三大栄養素の摂取を考慮する場 合」「熱量の摂取と三大栄養素とビタミンの摂取を考慮 する場合」の 3 つを想定しそれぞれ「制約条件なし」

「最大摂取量を制約条件とする」「最大摂取量と最小摂 取量を制約条件とする」とした合計 9 シナリオを設定し た(表-4). シナリオ(1)〜(3)では熱量のみ基準值を満たし ていれば良いが，シナリオ(7)〜9では熱量と三大栄養素 とビタミンの全ての基準值を満たす必要がある. シナリ オ(9が最も実生活に近い.

\section{(2)結果}

\section{a) 低炭素型の食生活の最適化}

各食料の摂取熱量, 投入エネルギーの 2009 年推計值 と各シナリオの最適值を表 -5 に示寸. 表 -5 には各食料 の摂取熱量の合計, 摂取熱量 $1 \mathrm{kcal}$ あたりの投入エネル ギーも掲載し，各シナリオ間で比較できるようにした.

表-4 シナリオの条件と番号

\begin{tabular}{|c|c|c|}
\hline 考慮項目 & 制約条件 & シナリオ番号 \\
\hline \multirow{3}{*}{ 熱量のみ } & なし & (1) \\
\hline & 最大摂取熱量 & (2) \\
\hline & 最大恸取熱量と最小㩒取熱量 & (3) \\
\hline \multirow{3}{*}{$\begin{array}{c}\text { 熱量と三大 } \\
\text { 栄養素 }\end{array}$} & なし & (4) \\
\hline & 最大摂取量* & (5) \\
\hline & 最大摂取量と最小摂取量* & (6) \\
\hline \multirow{3}{*}{$\begin{array}{c}\text { 熱量と三大 } \\
\text { 栄養素とビ } \\
\text { タミン }\end{array}$} & なし & (7) \\
\hline & 最大摂取量* & (8) \\
\hline & 最大摂取量と最小摂取量* & (9) \\
\hline
\end{tabular}

* : 熱量, 栄養素, ビタミンの摂取を含む

表-5 低炭素型の食生活の最適化の結果

\begin{tabular}{|c|c|c|c|c|c|c|c|c|c|c|}
\hline $\begin{array}{c}\text { 単位 } \\
{[\mathrm{kcal}]}\end{array}$ & 2009 & (1) & (2) & (3) & (4) & (5) & (6) & (7) & (8) & (9) \\
\hline 就類 & 785.0 & 0.0 & 1401 & 1244 & 0.0 & 1433 & 1054 & 0.0 & 1387 & 1042 \\
\hline いも類 & 38.0 & 0.0 & 84.4 & 84.4 & 1063 & 84.4 & 84.4 & 994.5 & 84.4 & 84.4 \\
\hline 頭 & 65.0 & 1606 & 120.3 & 120.3 & 538.7 & 120.3 & 120.3 & 537.5 & 1203 & 120.3 \\
\hline 野菜類 & 70.0 & 0.0 & 0.0 & 51.0 & 0.0 & 0.0 & 51.0 & 742. & 0.0 & 51.0 \\
\hline 果实類 & 67.0 & 0.0 & 0.0 & 12.4 & 0.0 & 0.0 & 12.4 & 0.0 & 73.0 & 22.7 \\
\hline 肉類 & 174.0 & 0.0 & 0.0 & 14.5 & 0.0 & 193.2 & 177.4 & 0.0 & 193.2 & 177.8 \\
\hline 魪介類 & 113.0 & 0.0 & 0.0 & 72.9 & 0.0 & 0.0 & 72.9 & 0.0 & 0.0 & 72.9 \\
\hline 乳製品 & 88.0 & 0.0 & 0.0 & 63 & 0.0 & \begin{tabular}{|l}
102.8 \\
\end{tabular} & 102.8 & 0.0 & 102.8 & \begin{tabular}{|l}
102.8 \\
\end{tabular} \\
\hline 摂取熱量 & 1400 & 1606 & 1606 & 1606 & 1601 & 1933 & 1903 & 1606 & 1961 & 1674 \\
\hline $\begin{array}{c}\text { 投入エネ } \\
\text { ルギー }\end{array}$ & 4950 & 743.6 & 2298 & 2060 & 1023 & 3704 & 4588 & 1659 & 3844 & 4600 \\
\hline $\begin{array}{c}\text { 摂取熱量 } \\
\text { lkcal あたり } \\
\text { の投入环神゙ー }\end{array}$ & 3.54 & 0.46 & 1.43 & 128 & 0.64 & 1.92 & 2.74 & 1.03 & 1.96 & 2.75 \\
\hline
\end{tabular}

\section{b) 二酸化炭素排出量}

食料摂取における二酸化炭素排出量の 2009 年推計値 と各シナリオの最適值を図-15 に示す. 考慮項目が少な いほど，また制約条件も少ないほど，二酸化炭素排出量 を抑制できた，最も実生活に近いシナリオ(9)では，約 500 万 $\mathrm{tCO}_{2}$ を削減できることが明らかになった．これは， 2009 年推計值の $7 \%$ に相当する.

\section{c) 食品口ス量}

食品ロス量の 2009 年推計值及び各シナリオの最適値 を図-16 に示す。二酸化炭素削減量のグラフと異なり, 考慮項目や制約条件等で規則性が見られなかった。 熱量 と三大栄養素とビタミンを考慮し, 最大摂取熱量と最小 摂取熱量を制約条件として一番実生活に近いシナリオ(9) では, 2009 年の食品ロス量と比較して $123 \%$ に増加する。 また，シナリオ(4)とシナリオ(7)は約 400\%の増加という 大きい值となった. この原因として, いも類の食品ロス 率が考えられる，いも類の食品ロス率は，13\%と他の食 品に比べて大きい(表-6). いも類は投入エネルギーが低 いため，低炭素型の食生活では摂取が多くなるが，その 分いも類の食品ロスも増加し, 結果として全体的に食品

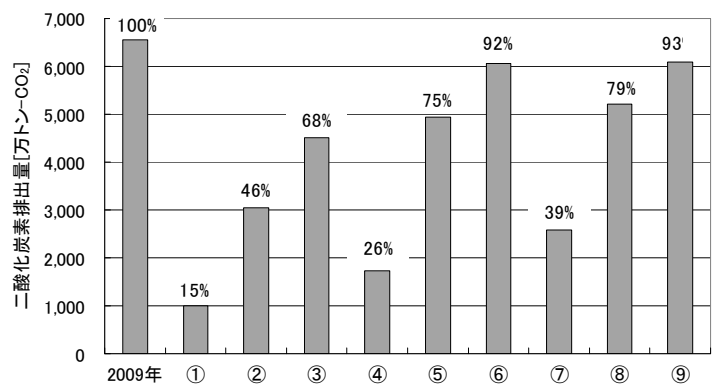

図-15 2009 年推計值と各シナリオの最適值の比較 (数字は 2009 年を 100 とした時の二酸化炭素排出量)

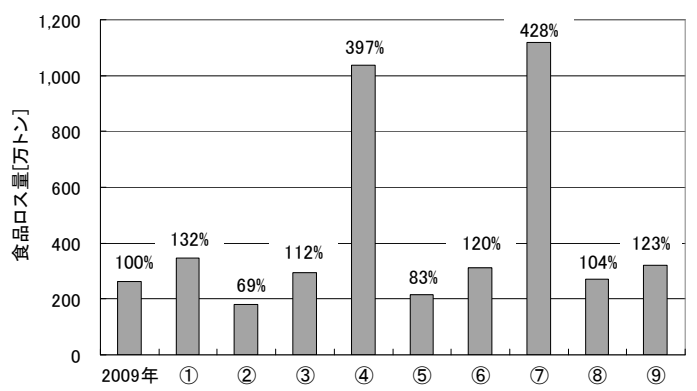

図-16 2009 年と各シナリオの食品ロス量の比較 (数字は 2009 年を 100 とした時の食品ロス量)

表-6 各食料の食品ロス率 $(\%)$

\begin{tabular}{|c|c|c|c|c|c|c|c|}
\hline 款類 & (も類 & 豆類 & 野菜類 & 果実類 & 肉類 & 魚介類 & 乳製品 \\
\hline 2.2 & 13.0 & 5.5 & 10.3 & 10.0 & 4.4 & 5.8 & 2.3 \\
\hline
\end{tabular}


ロスが増加したのだと考えられる。

\section{d）低炭素型の食生活について}

最も実生活に近いシナリオ(9)と 2009 年の摂取熱量を 比較する. 表-5 より, シナリオ(9)は, 穀類・いも類・ 豆類・肉類 - 乳製品の摂取を増加し, 野菜類 - 果実類 · 魚介類の摂取を減少させる食生活である. 穀類・いも 類・豆類はそれぞれ，投入エネルギーが低いことが増加 する結果になったと考える. 一方, 漁業・養殖業に多量 の燃料が必要であること, 野菜類・果実類は投入エネル ギーに対する捸取熱量が低いため，最適化においてそれ ぞれ摂取熱量が抑制されたものと考えられる．また，肉 類や乳製品も投入エネルギーは大きいが，たんぱく質や 脂質を効率良く摂取するために必要不可欠であり, 結果 的に摂取熱量が増加したと考えられる.

野菜類・果実類が摂取熱量に対して投入エネルギーが 多いことはシナリオ(1) - (6における野菜類・果実類の優 先順位を低いものとし野菜類・果実類の摂取不足が懸念 されるため, シナリオ(7)- (9)でその解消を図った. しか し，ビタミンを考慮項目に含むか含まないかの違いであ るシナリオ(6)と(9)では，野菜類と果実類の摂取熱量は大 きく変化しなかった．これより，野菜類・果実類の不足 を補うためには, ビタミン以外の栄養素も考慮する必要 があることが明らかになった。

シナリオ(9)では食品ロス量が増加するという結果が得 られた. 本研究は食品廃棄物の処理は考慮しておらず, 処理に伴う熱量投入も考慮していない. ただし, 食品口 スが持つ熱量は投入エネルギーよりも小さく, 食品ロス の増加による熱量ロスの増加よりも，投入エネルギーの 減少の方が全体へ与える影響が大きいことから今回は食 品ロスの増加に関しては十分な考察は行っていない. し かしながら, 将来的には食品口ス量も考慮した多目的最 適化を検討寸る必要があろう。

\section{e)低炭素型の需給システムの提案}

シナリオ(9)の食生活の場合，野菜類・果実類・魚介類 の摂取熱量が減少分は，食料自給率や輸送エネルギーな どを考慮して，国内生産の縮小ではなく輸入量の削減で 対応することが望ましいと考える。，一方，摂取熱量を増 加させるべき食料については, 国内での生産量を増加さ せることが望ましい．特に豆類は，1965年に $25 \%$ \%った 自給率が 2010 年では $8 \%$ まで咸少したが，本研究では 2009 年の約 2.2 倍に増加させるべきとの結果になった. 豆類の自給率が伸び悩む原因として，単収が低くかつ豊 凶変動があり収益が安定しないこと, 機械化が遅れ多労 を要することが作付意欲を減少したことがあげられる 28)。しかし，低炭素化を考慮した農業政策において豆 類の国内生産量増加は, 一つの方向性として検討される ベきであると考える.

\section{4. 結論}

本研究では，食料フローと食品ロス量の算出による環 境負荷評価を行ったとともに，食生活が抱える問題であ る環境負荷低減と必要栄養素摂取という環境・生活の両 面からの解決を試みる「低炭素型の食生活」の検討を行 った.

食料生産に伴う二酸化炭素排出量は 2009 年において 約 5000 万 $\mathrm{tCO}_{2}$ であり, 日本の二酸化炭素総排出量の約 4.5\%を占め, 減少傾向ではあるが高い水準であること が明らかになった。また，供給熱量と摂取熱量の乘離幅 と食品廃棄物による熱量ロス量の值がほぼ同等になり, 乘離幅の熱量ロスは廃棄物となっている可能性が高いこ とが判明した．しかしながら，より詳細な分析をするた めには各部門の食品廃棄物量を積み上げて食品廃棄物に よる熱量ロスを計算し，評価することが望まれる．

また，線形計画法を用いて基準值以上の熱量及び栄養 素量の摂取を満たしながら，投入エネルギーが最も少な い食生活の最適解を求めた. その結果, 穀類・いも類 豆類 - 肉類 - 乳製品の摂取を増加し, 野菜類 - 果実類 魚介類の摂取を減少させる解が得られた。 そして, 2009 年の食料由来の二酸化炭素排出量に対して, 年間で約 500 万 $\mathrm{tCO}_{2}$ の削減が可能であることが明らかになった.

本研究の結果は，消費者への情報提示や農業政策や指 針の決定だけでなく，線形計画法を用いた食料摂取の最 適解を求める新たな手段として, 食生活に関する環境問 題の解決手法の提案が可能だと期待できる.

注

（1）食品廃棄物とは食品由来の廃棄物であり，食品ロス とはそのうちの可食部分である. 本研究では廃棄物 や炭酸ガス排出に関する場合は食品廃棄物, 食品由 来と統一した，なお，食料需給，食料自給率等，慣 例的に「食料」が用いられている場合はそのまま 「食料」を用いた。

(2)粗食料とは 国内消費仕向量一（飼料用十種子用十加 工用十減耗量）のことであり，国内消費仕向量とは 国内生産量十輸入量一輸出量土在庫量で定義される.

\section{参考文献}

1）環境省 : 食品廃棄物の処理状況（平成 20 年度）, http://www.env.go.jp/doc/toukei/contents/index.html

2）農林水産省：食品口スの削減に向けて（平成 24 年）, http://www.maff.go.jp/j/shokusan/recycle/syoku_loss/pdf /0902shokurosu.pdf

3）財団法人食品産業センター，食品リサイクル法, http:/www.shokusan.or.jp/kankyo/shoku/

4）農林水産省 : 食料需給表（平成 22 年度版）, http://www.maff.go.jp/j/zyukyu/fbs/index.html 
5）農林水産省：食料・農業・農村白書（平成 21 年度版）, http:/www.maff.go.jp/j/wpaper/w_maff/h21_h/trend/part1/terminology.html\#ygk004

6）独立行政法人国立環境研究所 : 温室効果ガスインベントリ オフィス, http://www-gionies.go.jp/index-j.html

7）小幡範雄 : 食に関連した環境負荷の削減と持続可能な食と 農に関する研究，政策科学，Vol.19, No.3，pp.249-267，2012

8）佐藤 善暁 : 産業連関表を用いた食料品部門のエネルギー・ 環境負荷分析，筑波大学第三学郡国際総合分類卒業論文， 2007

9) Apaiah, R.K., Linnemann,A.R., van derKooi,H.J. : Exergy analysis: A tool to study the sustainability of food supply chain, Food Research Intemational, Vol.39, No.1-11, 2006

10) FAO : Global Food losses and Food Waste, 2011

11）須藤裕之，菱田次考：わが国の食料自給率と食品ロスの 問題について，名古屋文理大学紀要，第 10 号，2010

12） Kantor, L. S.， Lipton, K.， Manchester, A.，Oliveira, V. : Estimating and addressing America's food losses, FoodReview, Vol.20, Issue1, pp.2-12, 1997

13) Parfitt, J., Barthel, M., Macnaughton, S. : Food waste within food supply chains:quantification and potential for changeto 2050, Philosophical Transactions of The Royal Society B: Biological Sciences , Vol.365, No.1554, pp.3065-3081，2010

14）野口 良造, 齋藤 高弘：インベントリ分析による機械化水 稲生産のエネルギー消費・効率の考察，農業情報研究， Vol.17, No.1, pp.20-30, 2008

15）仁平 尊明 : 日本における作物生産の投入・産出エネルギ 一の算出, 人文地理学研究, No.27, pp.13-32, 2003

16）吉川直樹，天野耕二，島田，幸司 : 輸入食料・飼料の環
境負荷を考慮した産業連関表による $\mathrm{CO}_{2}$ 排出原単位の作成, 第4回日本 LCA 学会研究発表会, 2009

17) 澤田 学: 栄養摂取コストの推計 : 昭和 32〜 56 年全国平均農 家，帯広畜産大学研報 I ，Vol.17，pp.185-190，1991

18）久保勇, 長沢啓行，西山徳幸 : 栄養摂取計画における多 目的意思決定システム, 日本経営工学会誌, Vol.39, No.2, pp.76-82, 1988

19）社団法人産業環境管理協会 : カーボンフットプリントコミ ユニケーションプログラム, http://www.cfp-japan.jp/

20）唯是 康彦, 三浦 洋子: 食料消費資料の数量的整合性一食 品ロスの統計を中心にして一，統計学，Vol.87，pp.28-42， 2004

21）農林水産省大臣官房統計情報部 : 食品口ス統計調查報告 9 (平成 12 年度)，2002，農林統計協会，pp.1-81

22）農林水産省大臣官房統計情報部 : 食品循環資源の再生利用 等実態調査結果の概要（平成 21 年度結果）,2011

24）厚生労働省 : 国民健康・栄養調查, http:/www.mhlw.go.jp/bunya/kenkou/kenkou_eiyou_chousa.html

25）農林水産省

http:/www.maff.go.jp/j/wpaper/w_maff/h22 h/trend/part1/topics $/ 302 . h t m l$

26）三神 彩子 : 環境に配慮した食生活「エコ・クッキング」 が地球環境問題の改善に与える影響，日本調理科学会誌， Vol45, No.5, 323-331(2012)

27）環境省 : 環境統計集, http:/www.env.go.jp/doc/toukei/contents/index.htmll\#shokuhinrisaikunu

28）農林水産省 : 消費者の部屋 $\mathrm{Q} \& \mathrm{~A}$, http:/www.maff.go.jp/jheya/kodomo_sodan/0308/05.html

(2014. 8. 4 受付)

\section{RESEARCH OF MATERIAL AND ENERGY ANALYSIS ON FOOD SUPPLY SYSTEM AND LOW CARBON EATING HABITS}

\section{Yusuke NAGANUMA, Junzo TACHIBANA and Naohiro GOTO}

For sustainable society, it is important to realize food supply and demand system which is low environmental load. Previous studies about the system focused on only an aspect, for example lifestyle, economy or environmental aspect. In this study we aimed at both environmental load and lifestyle.

Firstly, we analyzed material flow on food supply-demand system by input output table. Then we estimated amount of food consumption, food loss, energy input to production of food and carbon dioxide emissions. As the result, this study found that approximately 50 million $\left[\mathrm{t}-\mathrm{CO}_{2}\right]$ carbon dioxide emissions in 2009 . This is accounting for $4.5 \%$ of the total carbon dioxide emissions in Japan.

In the next, we investigated possibility of the food supply-demand system which reduce environmental load and meet the quantity of nutritive substances which need to intake each day. To estimate we used linear programming whose limiting condition were quantity of nutritive substances and objective function were minimization of environmental load. As the result, environmental load was minimized when the intake of Cereals, Potatoes, Beans, Meat and Dairy products increased, while Vegetables, Fruits and Seafood reduced. When all Japanese people realize this diet system, the reduction of carbon dioxide must be 5 million $\left[\mathrm{t}-\mathrm{CO}_{2}\right]$ per year in approximately. 